\title{
Determination of Cadmium and Zinc in Fertilizer Samples by FAAS after Solid-Phase Extraction with Freshly Precipitated Manganese-diethyldithiocarbamate
}

\author{
Hasan CESUR ${ }^{\dagger}$ and Çiğdem AKSU \\ Ondokuz Mayıs University, Faculty of Science and Arts, Department of Chemistry, TR-55139 Samsun, Turkey
}

\begin{abstract}
Using freshly precipitated manganese-diethyldithiocarbamate $\left(\mathrm{Mn}(\mathrm{DDTC})_{2}\right)$ as a new reagent, a solid phase extraction method (SPE) has been developed for the extraction of $\mathrm{Cd}(\mathrm{II})$ and $\mathrm{Zn}(\mathrm{II})$ in aqueous fertilizer samples. A sample solution of $300 \mathrm{~mL}$ was taken and $0.10 \mathrm{~g}$ of freshly precipitated $\mathrm{Mn}(\mathrm{DDTC})_{2}$ was added. After adding a phosphate buffer solution, the mixture was stirred at $10 \mathrm{~min}$, filtered with a glass filter and washed with deionized water. The solid product containing $\mathrm{Mn}(\mathrm{DDTC})_{2}-\mathrm{Cd}(\mathrm{DDTC})_{2}-\mathrm{Zn}(\mathrm{DDTC})_{2}$ complexes was dissolved in concentrated nitric acid and its volume was made complete up to $10 \mathrm{~mL}$ with deionized water. The metal contents of the solution were measured by an atomicabsorption spectrometer.
\end{abstract}

(Received November 11, 2005; Accepted January 30, 2006)

Flame atomic-absorption spectrometry (FAAS) is one of the most popular techniques for the determination of trace metals in industrial fertilizers or some environmental samples, due to being useful, inexpensive and selective. However, for extremely low analyte concentrations and matrix effects (such as $\mathrm{PO}_{4}^{3-}, \mathrm{Cl}^{-}$and $\mathrm{SO}_{4}{ }^{2-}$ ions) a preliminary preconcentration or separation technique is required.

The solid phase extraction method (SPE) is generally used for the preconcentration of metal ions in various matrices. ${ }^{1-6}$ In this technique, the dithiocarbamate extraction method is a useful means of enrichment, and dithiocarbamates do not react with many metals that are fairly abundant in environmental samples. To the preconcentration of trace metals, it has been applied prior to their determination by UV-VIS spectrophotometry, ${ }^{7-15}$ AAS, ${ }^{16-21}$ ICP-AES ${ }^{22,23}$ and electroanalytical method. ${ }^{24,25}$

In these studies, sodium diethyldithiocarbamate (NaDDTC), ammonium pyrolidinedithiocarbamate (APDC) or ammonium hexamethylenedithiocarbamate (HMDC) reagent was added to an aqueous phase containing several metals. Then, metaldithiocarbamate complexes were formed and all of them were extracted on a solid phase, such as activated carbon, polyurethane foam, silica gel or amberlite XAD resins. In these applications, there were some difficulties, such as dithiocarbamate anions that decomposed in aqueous acidic medium. The selective extraction of the metal ions could not be achieved.

On the other hand, several dithiocarbamate reagents have been used prior to an atomic-absorption spectrometric determination for the preconcentration of trace metals, as a coprecipitant with a carrier element, such as $\mathrm{Ni}(\mathrm{II})^{26}$ and $\mathrm{Bi}(\mathrm{III}) .{ }^{27}$ In this method, the selective extraction of the metal ions is not possible because some ions in solution simultaneously precipitate when the precipitation occurs with a carrier element.

In our preceding work, freshly precipitated metal diethyldithiocarbamates $\quad\left(\mathrm{Mn}(\mathrm{DDTC})_{2}, \quad \mathrm{Zn}(\mathrm{DDTC})_{2}\right.$,

$\dagger$ To whom correspondence should be addressed.

E-mail: hasanc@omu.edu.tr
$\mathrm{Cd}(\mathrm{DDTC})_{2}, \quad \mathrm{Fe}(\mathrm{DDTC})_{3}, \quad \mathrm{Co}(\mathrm{DDTC})_{2}, \quad \mathrm{Cu}(\mathrm{DDTC})_{2}$, $\mathrm{Ni}(\mathrm{DDTC})_{2}, \mathrm{~Pb}(\mathrm{DDTC})_{2}$ and $\left.\mathrm{Hg}(\mathrm{DDTC})_{2}\right)$ were tested as reagents for the selective extraction of $\mathrm{Mn}(\mathrm{II}), \mathrm{Zn}(\mathrm{II}), \mathrm{Cd}(\mathrm{II})$, $\mathrm{Fe}(\mathrm{III}), \mathrm{Co}(\mathrm{II}), \mathrm{Cu}(\mathrm{II}), \mathrm{Ni}(\mathrm{II}), \mathrm{Pb}(\mathrm{II})$ and $\mathrm{Hg}(\mathrm{II})$ ions from aqueous solution. It was found that these reagents show excellent selectivity for the extraction of metal ions..$^{28}$

In this present study, a new application of these reagents was carried out, where freshly precipitated $\mathrm{Mn}(\mathrm{DDTC})_{2}$ was used for the preconcentration of $\mathrm{Cd}$ and $\mathrm{Zn}$ in an aqueous system prior to their determination by FAAS. The aim of this work was to investigate the optimum conditions for the selective extraction and atomic-absorption spectrophotometric determination of $\mathrm{Cd}$ and $\mathrm{Zn}$ in some fertilizer samples.

\section{Experimental}

\section{Apparatus and reagents}

An ATI-UNICAM 929 Model flame atomic-absorption spectrophotometer was used for the determination of metal ions. $\mathrm{pH}$ measurements were performed with a JENWAY 3040 Model digital $\mathrm{pH}$-meter. $\mathrm{C}, \mathrm{H}, \mathrm{N}$ and $\mathrm{S}$ analyses were carried out by CHNS-932 (LECO) at the TUBITAK ATAL Research Centre (Ankara). Sodium salt of diethyldithiocarbamic acid was purchased from E. Merck. $\mathrm{Cd}(\mathrm{II})$ and $\mathrm{Zn}$ (II) stock solutions $\left(0.1 \mathrm{~mol} \mathrm{~L}^{-1}\right)$ were prepared by dissolving appropriate amounts of their nitrate salts. Standard solutions for AAS were prepared with the stock metal solutions. Deionized water was produced by ELGA Maxima Ultra Pure Water Systems. Other reagents were of analytical reagent grade.

\section{Preparation of $\mathrm{Mn}(\mathrm{DDTC})_{2}$ precipitate}

A $\mathrm{Mn}(\mathrm{II})$ solution in water $\left(0.1 \mathrm{~mol} \mathrm{~L}^{-1}\right)$ and a NaDDTC solution $\left(0.1 \mathrm{~mol} \mathrm{~L}^{-1}\right)$ in water were mixed in stochiometric ratio, and $\mathrm{Mn}(\mathrm{DDTC})_{2}$ was precipitated. The precipitant was filtered with filter paper by a vacuum pump. It was washed with deionized water and stored in a flask while being 


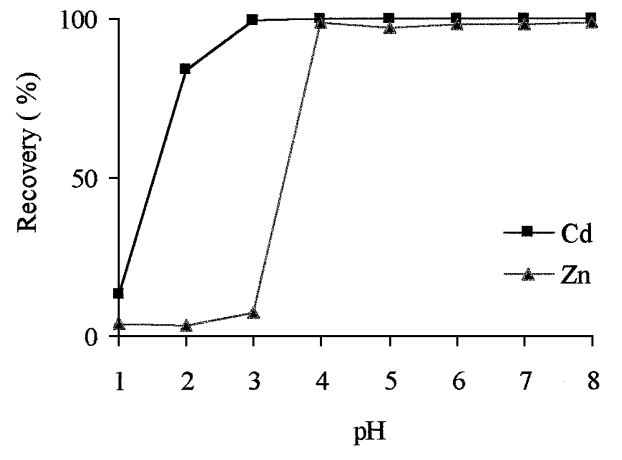

Fig. 1 Effect of the $\mathrm{pH}$ for the preconcentration of cadmium and zinc.

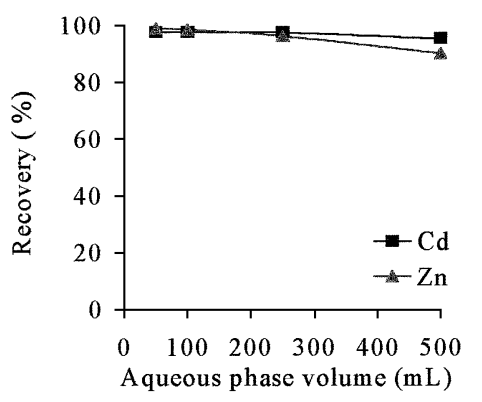

Fig. 2 Effect of the aqueous phase volume on the preconcentration of cadmium and zinc.

somewhat damp. If the metal dithiocarbamate was dried, it became fixed in the water solution during the extraction procedure, and was not completely mixed with the aqueous phase.

$\mathrm{Mn}(\mathrm{DDTC})_{2}$ was dried at $110^{\circ} \mathrm{C}$ for $24 \mathrm{~h}$. The humidity was found to be $30.2 \%$. Dried $\mathrm{Mn}(\mathrm{DDTC})_{2}$ was characterized by elemental analysis. The calculated and found (in parentheses) C, H, N and S were 34.20 (34.18), 5.70 (5.14), 7.97 (7.76) and 36.47 (36.91).

\section{General procedure}

A solution of $300 \mathrm{~mL}$, containing $30-200 \mu \mathrm{g} \mathrm{Cd}(\mathrm{II})$ and $\mathrm{Zn}$, was placed in an Erlenmeyer flask, and $0.10 \mathrm{~g}$ of freshly precipitated $\mathrm{Mn}(\mathrm{DDTC})_{2}$ was added. After adding the phosphate buffer solution, the mixture was stirred at $10 \mathrm{~min}$, filtered with a glass filter and washed with deionized water. The solid product containing $\mathrm{Mn}(\mathrm{DDTC})_{2}-\mathrm{Cd}(\mathrm{DDTC})_{2}-$ $\mathrm{Zn}(\mathrm{DDTC})_{2}$ complexes was dissolved in concentrated nitric acid and its volume was made up $10 \mathrm{~mL}$ with deionized water. The metal contents of the solution were measured by an atomicabsorption spectrophotometer.

\section{Results and Discussion}

\section{Effect of the $p H$}

The SPE productivity depends on various parameters. The $\mathrm{pH}$ is one of the most important parameters, and first of all $\mathrm{pH}$ must be determined. For this purpose, $50 \mathrm{~mL}$ of solutions containing $5 \mu \mathrm{g}$ of a cadmium and zinc solution were taken, and the $\mathrm{pH}$ was adjusted by $\mathrm{HNO}_{3}$ and $\mathrm{KOH}$ solutions. The other parameters being constant, the general procedure was applied and the concentrations of metals were measured by FAAS. The results presented in Fig. 1 indicate that the extraction of

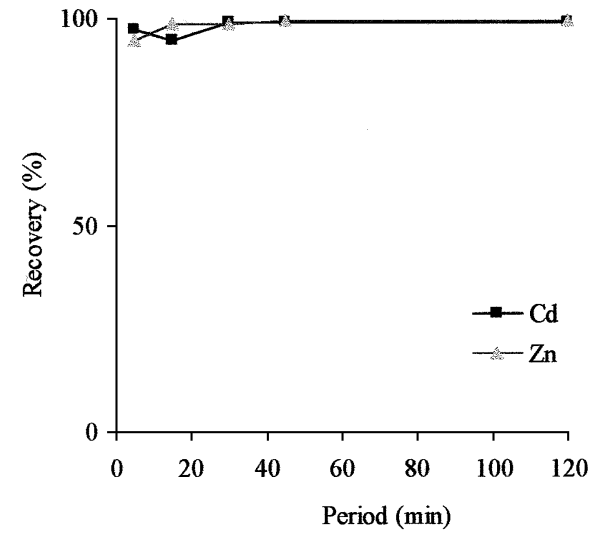

Fig. 3 Effect of extraction period for the preconcentration of cadmium and zinc.

cadmium and zinc on solid $\mathrm{Mn}(\mathrm{DDTC})_{2}$ has no effect between pH $4-7$.

The stability of metal-DDTC depends on the $\mathrm{pH}$. A higher stability constant of metal-DDTC means more stable in acidic solutions; also, sorption can be carried out at low $\mathrm{pH}$ degrees. The stability constant of $\mathrm{Cd}(\mathrm{DDTC})_{2}$ is greater than that of $\mathrm{Zn}(\mathrm{DDTC})_{2}$, and $\mathrm{Cd}(\mathrm{II})$ can be extracted in a more acidic solution.

\section{Effect of the aqueous phase volume}

The volume of the aqueous phase is an important factor for the extraction of metal ions. To determine the effect of the volume of the aqueous phase, cadmium and zinc solutions (containing $5 \mu \mathrm{g} \mathrm{mL}^{-1}$ of $\mathrm{Cd}(\mathrm{II})$ and $\mathrm{Zn}(\mathrm{II})$ ) were diluted from 50 to $500 \mathrm{~mL}$ by deionized water, and the metal content was analyzed by the general procedure. The results are presented in Fig. 2. It was shown that the cadmium and zinc concentrations remained constant up to $500 \mathrm{~mL}$. It is indicated that the exchange reaction of metals is rapid, and the efficiency is high. The aqueous phase volume was selected to be $300 \mathrm{~mL}$ for confidence. The enrichment factor achieved for the proposed method was 30 .

\section{Effect of the extraction period}

The extraction period was also studied; cadmium and zinc solutions (containing $5 \mu \mathrm{g} \mathrm{mL} \mathrm{m}^{-1}$ of $\mathrm{Cd}(\mathrm{II})$ and $\mathrm{Zn}(\mathrm{II})$ ) extracted at various periods according to previously described procedure and the absorbance of metals measured by FAAS. The results are presented in Fig. 3. It was observed that the quantitative extraction of $\mathrm{Cd}$ and $\mathrm{Zn}$ was completed at $5 \mathrm{~min}$. The extraction time was selected to be 10 min for confidence.

\section{Effect of diverse ions}

Chemical fertilizers generally consist of alkali metal ions (or $\mathrm{NH}_{4}^{+}$) and anions such as nitrate, chloride, phosphate or sulfate. Therefore, to investigate an interfering effect of the diverse ions, saturated salt solutions were used. A metal solution (containing $5 \mu \mathrm{g} \mathrm{mL}^{-1}$ of $\mathrm{Cd}(\mathrm{II})$ and $\mathrm{Zn}(\mathrm{II})$ ) and different amounts alkali metal salt solutions were prepared. The determinations of cadmium and zinc contents were carried out by the general procedure. The results given in Table 1 indicated that many of the salts and metal ions can be tolerated up to saturated levels.

\section{Sorption capacity of the solid $\mathrm{Mn}(\mathrm{DDTC})_{2}$}

The freshly precipitaded $\mathrm{Mn}(\mathrm{DDTC})_{2}$ solid-phase sorption 
Table 1 Effect of diverse salts on the determination of cadmium and zinc

\begin{tabular}{|c|c|c|}
\hline Salt & $\begin{array}{l}\text { Tolerance limit }{ }^{\mathrm{a}} \text { for } \\
\mathrm{Cd} / \mathrm{g} \mathrm{L}^{-1}\end{array}$ & $\begin{array}{l}\text { Tolerance limit }{ }^{\mathrm{a}} \text { for } \\
\mathrm{Zn} / \mathrm{g} \mathrm{L}^{-1}\end{array}$ \\
\hline $\mathrm{KCl}$ & 140 & 140 \\
\hline $\mathrm{Na}_{2} \mathrm{SO}_{4}$ & 70.6 & 70.6 \\
\hline $\mathrm{KNO}_{3}$ & 120 & 120 \\
\hline$\left(\mathrm{NH}_{4}\right)_{3} \mathrm{PO}_{4}$ & 60 & 60 \\
\hline $\mathrm{KBr}$ & 120 & 120 \\
\hline $\mathrm{NaAc}$ & 60.2 & 60.2 \\
\hline$\left(\mathrm{NH}_{4}\right)_{2} \mathrm{SO}_{4}$ & 200 & 200 \\
\hline $\mathrm{NaCl}$ & 160 & 160 \\
\hline
\end{tabular}

a. Tolerance limit was taken as the amount causing an error of $\pm 5 \%$ in absorbance.

Table 2 Linear ranges, calibration equations, limit of detections and limit of quantifications

\begin{tabular}{cccccc}
\hline & Linearity & Equation & $R^{2}$ & LOD & LOQ \\
\hline $\mathrm{Cd}$ & $0.2-3$ & $y=0.118 x+0.025$ & 0.983 & 0.04 & 0.08 \\
$\mathrm{Zn}$ & $0.2-4$ & $y=0.134 x+0.014$ & 0.993 & 0.25 & 0.49
\end{tabular}

capacity was studied. A metal solution of $100 \mathrm{~mL}\left(0.1 \mathrm{~mol} \mathrm{~L}^{-1}\right)$ was taken and $0.1 \mathrm{~g}$ of freshly precipitated $\mathrm{Mn}(\mathrm{DDTC})_{2}$ was added. To adjusted the $\mathrm{pH}$ of the solution, a phosphate buffer solution was added. The procedure was applied and the metal contents were measured by AAS. The results demonstrated that $1.00 \mathrm{~g}$ of freshly precipitated $\mathrm{Mn}(\mathrm{DDTC})_{2}$ had a capacity of 199 $\mathrm{mg}$ of $\mathrm{Cd}(\mathrm{II})$ and $116 \mathrm{mg}$ of $\mathrm{Zn}(\mathrm{II})$.

The sorption of the metal ions was carried out by exchanging $\mathrm{Mn}(\mathrm{II})$ and $\mathrm{Cd}(\mathrm{II})_{(\mathrm{aq})}$ or $\mathrm{Zn}(\mathrm{II})_{(\mathrm{aq})}$ species on freshly precipitated $\mathrm{Mn}(\mathrm{DDTC})_{2}$;

$$
\mathrm{Mn}(\mathrm{DDTC})_{2(\mathrm{~S})}+\mathrm{Cd}^{2+}{ }_{(\mathrm{aq})} \rightleftharpoons \mathrm{Cd}(\mathrm{DDTC})_{2(\mathrm{~S})}+\mathrm{Mn}^{2+}{ }_{(\mathrm{aq})}
$$

The stability of metal-DDTC's decreases in the following order: $\mathrm{Hg}, \mathrm{Cu}, \mathrm{Pb}, \mathrm{Ni}, \mathrm{Cd}, \mathrm{Fe}, \mathrm{Co}, \mathrm{Zn}$ and $\mathrm{Mn}$. The element can be displaced from its diethyldithiocarbamate compound only by elements to the left of it in the series. ${ }^{28}$ However, the sorption capacity depends on several parameters, such as the stability constant of metal DDTC's, the $\mathrm{pH}$ and kinetics factors.

\section{Calibration curve, linearity and sensitivity}

The calibration graph was constructed with ten standard solutions containing $0.1-20 \mu \mathrm{g} \mathrm{mL} \mathrm{mL}^{-1}$ of cadmium or zinc according to the general procedure. The range of linearity was determined to be $0.2-3 \mu \mathrm{g} \mathrm{mL} \mathrm{mL}^{-1}$ for cadmium and $0.2-4 \mu \mathrm{g}$ $\mathrm{mL}^{-1}$ for zinc. The linearly ranges, regression equation and correlation coefficient were obtained by the method of least squares. The limit of detection and the limit of quantification were evaluated as the concentration corresponding to three times and ten-times the standard deviation of the blank signal, respectively. The results are presented in Table 2 .

\section{Determination of $\mathrm{Cd}$ and $\mathrm{Zn}$ in fertilizer samples}

The proposed method was successfully applied to the determination of $\mathrm{Cd}(\mathrm{II})$, and $\mathrm{Zn}$ (II) in chemical fertilizer samples. Fertilizer samples were taken from TUGSAŞ (Turkiye Gübre Fabrikaları Sanayi Anonim Şirketi). The samples were dissolved in a nitric acid solution (1\%) and filtered. Freshly precipitated $\mathrm{Mn}(\mathrm{DDTC})_{2}(0.1 \mathrm{~g})$ was added. Their $\mathrm{pH}$ were
Table 3 Determination of $\mathrm{Cd}$ and $\mathrm{Zn}$ in fertilizer samples

\begin{tabular}{lcc}
\hline Fertilizer sample & $\mathrm{Cd} / \mu \mathrm{g} \mathrm{kg}{ }^{-1 \mathrm{a}}$ & $\mathrm{Zn} / \mu \mathrm{g} \mathrm{kg}{ }^{-1 \mathrm{a}}$ \\
\hline UREA & $\mathrm{LOQ}$ & $204 \pm 20$ \\
$\mathrm{KNO}_{3}$ & $\mathrm{LOQ}$ & $330 \pm 30$ \\
$\mathrm{NH}_{4} \mathrm{NO}_{3}$ & $17.2 \pm 1.4$ & $200 \pm 17$ \\
$\left(\mathrm{NH}_{4}\right)_{2} \mathrm{SO}_{4}$ & $7.1 \pm 1.5$ & $222 \pm 39$ \\
\hline
\end{tabular}

a. Mean of three determinations with $95 \%$ confidence level $(\bar{X} \pm t s / \sqrt{N})$.

Table 4 Determination of $\mathrm{Cd}$ and $\mathrm{Zn}$ in spiked fertilizer samples

\begin{tabular}{lccc}
\hline \multirow{2}{*}{$\begin{array}{c}\text { Fertilizer } \\
\text { sample }\end{array}$} & $\begin{array}{c}\text { Spiked Cd and } \\
\mathrm{Zn} / \mu \mathrm{g}^{-1}\end{array}$ & \multicolumn{2}{c}{ Found $^{\mathrm{a}}$} \\
\cline { 3 - 4 } & & $\mathrm{Cd} / \mu \mathrm{g}^{-1}$ & $\mathrm{Zn} / \mu \mathrm{g}^{-1}$ \\
\hline $\mathrm{UREA}$ & 1.00 & $0.92 \pm 0.03$ & $0.91 \pm 0.01$ \\
$\mathrm{KNO}_{3}$ & 1.00 & $0.89 \pm 0.02$ & $0.89 \pm 0.05$ \\
$\mathrm{NH}_{4} \mathrm{NO}_{3}$ & 1.00 & $0.79 \pm 0.16$ & $0.90 \pm 0.02$ \\
$\left(\mathrm{NH}_{4}\right)_{2} \mathrm{SO}_{4}$ & 1.00 & $0.98 \pm 0.05$ & $0.94 \pm 0.06$ \\
\hline
\end{tabular}

a. Mean of three determinations with $95 \%$ confidence level $(\bar{X} \pm t s / \sqrt{N})$.

Table 5 Determination of $\mathrm{Cd}$ and $\mathrm{Zn}$ in certified reference

\begin{tabular}{ccc}
\hline $\begin{array}{c}\text { BCR 32 Moroccan } \\
\text { phosphate rock }\end{array}$ & $\begin{array}{c}\text { Certified value/ } \\
\mu \mathrm{g}^{-1}\end{array}$ & $\begin{array}{c}\text { Found } \\
\mu \mathrm{g}^{-1}\end{array}$ \\
\hline $\mathrm{Cd}$ & 20.8 & $20.3 \pm 2.0$ \\
$\mathrm{Zn}$ & 253 & $248 \pm 15$ \\
\hline
\end{tabular}

a. Mean of three determinations with $95 \%$ confidence level $(\bar{X} \pm t s / \sqrt{N})$.

adjusted by a phosphate buffer and analyzed by the procedure. The results are presented in Table 3 .

Accuracy check of the method

For an accuracy check of the method, a certified reference material (CRM, BCR-32 Moroccan phosphate rock) and metal spiked ( $\mathrm{Cd}$ and $\mathrm{Zn}$ ) fertilizer samples were used. An aliquot of the solution of the certified material was taken and the metal contents were determined by the proposed method. The recovery values calculated for the standard additions were between $79-98 \%$ and for the certified reference material were $97-98 \%$. The results given in Tables 4 and 5 indicate that the certified and found values are very concordant.

\section{Conclusion}

SPE is currently popular and more advantageous than other techniques for the preconcentration of trace metal ions prior to their determination by AAS due to being rapid and simple, and allowing preconcentration from a larger volume of samples. The reactivity is very important in this technique, and dithiocarbamates do not react with many metals (such as IA and IIA groups metals), which are fairly abundant in fertilizer samples. Thus, selectivity can be achieved by using freshly precipitated manganese diethyldithiocarbamate in the solidphase extraction procedure. This method is based on the fact that the stability constants of the $\mathrm{Cd}$ and $\mathrm{Zn}$ dithiocarbamate complexes are greater than that of the $\mathrm{Mn}(\mathrm{DDTC})_{2}$ complex. Therefore, the metal ions in water rapidly exchange for $\mathrm{Mn}$ (II) on the $\mathrm{Mn}(\mathrm{DDTC})_{2}$ solid phase. The solid phase can be easily 
dissolved in nitric acid, and its absorbance can be measured by FAAS. Consequently, the proposed method is simple, selective, sensitive and accurate. It can be used for the determination of cadmium and zinc in fertilizer samples and other like samples.

\section{References}

1. P. Gopikrishna, K. S. Rao, T. P. Rao, and G. R. Naidu, Microchim. Acta, 2004, 114, 285.

2. G. Y. Yang, Q. F. Hu, H. J. Yang, Z. J. Huang, and Y. J. Yin, Anal. Sci., 2003, 19, 299.

3. Y. W. Liu, X. J. Chang, S. Wang, Y. Guo, B. J. Din, and S. M. Meng, Anal. Chim. Acta, 2004, 519, 173.

4. Y. Bakircioglu, S. Akman, N. Bicak, and F. Senkal, J. Trace Microprobe T, 2003, 21, 239.

5. R. J. Casella, O. I. B. Magalhaes, M. T. Couto, E. L. S. Lima, M. A. F. S. Neves, and F. M. B. Coitinho, Anal. Sci., 2005, 21, 939.

6. M. Soylak, L. Elci, and M. Dogan, J. Trace Microprobe T, 2001, 19, 329.

7. A. Kumar, M. F. Hussein, M. Stake, and B. K. Puri, Chim. Acta Turcica, 1983, 11, 337.

8. T. Khayamian, A. A. Ensafi, and B. Hemmateenejad, Talanta, 1999, 49, 587.

9. M. Andac, A. Asan, I. Isıldak, and H. Cesur, Anal. Chim. Acta, 2001, 434, 143.

10. A. Kumar, M. Jain, and B. K. Puri, Chim. Acta Turcica, 1990, 18,155 .
11. M. Kompany-Zareh, A. Massoumi, and H. Tavallali, Microchem. J., 1999, 63, 257.

12. Y. Sano, T. Kato, I. Nukatsuka, and K. Ohzeki, Bunseki Kagaku, 2003, 52, 1153.

13. H. Cesur and B. Bati, Turk. J. Chem., 2002, 26, 599.

14. B. Bati, H. Cesur, H. Bati, and M. Ozdemir, Turk. J. Chem., 1995, 19, 66.

15. N. Sing, K. Rostagi, R. Kumar, and T. N. Srivastava, Analyst, 1981, 106, 599.

16. B. Bati and H. Cesur, Anal. Sci., 2002, 18, 1273.

17. H. Cesur and B. Bati, Anal. Lett., 2000, 33, 489.

18. N. Tokman and S. Akman, Anal. Chim. Acta, 2004, 519, 87.

19. M. Soylak and L. Elci, Int. J. Environ. Anal. Chem., 1997, $66,51$.

20. H. Cesur, Turk. J. Chem., 2003, 27, 307.

21. K. Anezaki, X. Z. Chen, T. Ogasawara, I. Nukatsuka, and K. Ohzeki, Anal. Sci., 1998, 14, 523.

22. A. Ramesh, K. R. Mohan, K. Seshaiah, and N. D. Jegakumar, Anal. Lett., 2001, 34, 219.

23. S. Arpadjan, L. Vuchkova, and E. Kostadinova, Analyst, 1997, 122, 243.

24. S. Puri, R. K. Dubey, B. K. Puri, and M. F. Hussain, Anal. Lett., 1998, 31, 283.

25. S. Puri, R. K. Dubey, M. K. Gupta, and B. K. Puri, Talanta, 1998, 46, 655 .

26. H. Sato and J. Ueda, Anal. Sci., 2000, 16, 299.

27. H. Sato and J. Ueda, Anal. Sci., 2001, 17, 461.

28. H. Cesur, J. Trace Microprobe T, 2003, 21, 627. 